уДК 378.6(497.113 Сомбор):02

023-051(497.11)

doi: 10.19090/cit.2019.35.10-14

Прегледни рад

\title{
Библиотекарство у раљама живота: од школовања до запослења
}

\author{
Карла Селихар \\ Универзитет у Новом Саду \\ Педагошки факултет у Сомбору - Катедра за библиотекарство \\ selihar025@gmail.com \\ Жељко Вучковић \\ Универзитет у Новом Саду \\ Педагошки факултет у Сомбору \\ zeljko.sombor@yahoo.com
}

\begin{abstract}
Сажетак
У Републици Србији библиотекари се школују на две катедре - Катедри за библиотекарство и информатику Филолошког факултета Универзитета у Београду и Катедри за библиотекарство Педагошког факултета у Сомбору Универзитета у Новом Саду. Студије библиотекарства у Сомбору почињу 2005, а од 2015. године отвара се програм за мастер студије библиотекар-информатичар. У раду се прати развој студијског програма на Катедри у Сомбору и даљи пут студената свршених библиотекара. С обзиром на чињеницу да је сврха студијског програма образовање стручњака из библиотечкоинформационих наука, свршени библиотекари-информатичари су после четворогодишњих студија оспособљени за обављање послова у свим типовима библиотека. Увидом у документацију Педагошког факултета о броју уписаних и броју дипломираних студената анализираћемо и колико их је нашло посао у библиотекама.
\end{abstract}

Кључне речи: Педагошки факултет у Сомбору, студије библиотекарства, библиотекари, библиотеке, запошљавање, Република Србија

\section{Школовање библиотекара на Педагошком факултету у Сомбору}

Педагошки факултет у Сомбору започео је образовање школских библиотекара 2005. године. Студијски програм основних академских студија, у складу са захтевима Болоњске декларације, у трајању од три године, акредитовала је Комисија за акредитацију Универзитета у Новом Саду 2009. године. Наставом су били обухваћени општеобразовни, теоријско-методолошки, научно-стручни и стручно-апликативни предмети, који су организовани кроз обавезно и изборно подручје. Поред стручних предмета из области библиотекарства, студенти су добијали добру основу из општеобразовних предмета (попут српског језика, књижевности и математике), као и предмета из педагошко-психолошке области. Циљ овог студијског програма био је да „образује и оспособљава школског библиотекара за самостално обављање основних стручних библиотечко-информационих функција“, ${ }^{1}$ као и да се унапреди и побољша рад школских библиотека. Од школске 2005/06. године, на смер Школски библиотекар (од 2009. преименован у Библиотекар), до почетка студијског програма по новом програму 2014. године, на студијски програм уписано је 119 бруцоша, од којих је, по овом плану и програму, дипломирало 63 студента.

\footnotetext{
1 Жељко Вучковић, „Студије школског библиотекарства“, Паниеваико иишалишие 12 (мај 2008): 60-61.
} 
Када је започео нови акредитациони циклус, дошло је до битних измена студија библиотекарства у Сомбору. Од 2012. године акредитован је четворогодишњи смер основних академских студија: Библиотекар-информатичар. Сврха овог новог студијског програма била је образовање за професију која би требало да има све значајнију улогу у друштву информација и знања, а његов циљ јесте „образовање компетентних библиотекара-информатичара оспособљених за рад у савременим библиотекама, за размену информација и комуникацију у библиотечко-информационом систему“. ${ }^{2}$ Од 2014/15. до 2019/20. школске године смер Библиотекар-информатичар уписало је 60 студената, од којих је у међувремену 16 дипломирало.

Одлуком о еквиваленцији наставних планова и програма, свим студентима који су завршили трогодишње студије по плану и програму из 2005, 2006. и 2009. године, омогућено је дошколовање и завршетак основних четворогодишњих студија на смеру Дипломирани библиотекар-информатичар. ${ }^{3}$ Могућност дошколовања искористило је 50 студената. Звање дипломираног библиотекара-информатичара стекло је 24 студента на дошколовању.

Поређењем студијских програма из 2005. и 2014. године, може се приметити да је највише промена било у оквиру општеобразовних и теоријско-методолошких дисциплина. У новом студијском програму задржани су сви предмети из области библиотекарства: Савремено библиотекарство, Библиографија, Менаџмент и маркетинг у библиотекарству, Школске библиотеке, Историја писма, књиге и библиотека. Њима су додата три нова предмета - Високошколске и специјалне библиотеке, Јавне библиотеке и Претраживање научних информација. Из области стручно-апликативних предмета, студенти полажу и Каталогизацију, Класификационе системе, Библиотечко законодавство и стандарде, Савремено библиотекрство, Методику наставе информатике 1 и 2, као и Библиотечку праксу. Издвајају се и предмети из осталих група, попут Медијске културе, База података, Историје српске културе; изборни предмети међу којима се нуде Психологија комуникације, Увод у позоришну уметност, Математичко моделовање, и други. ${ }^{4}$ Изборни предмети студентима нуде целовитије знање о улози библиотекара у историјској перспективи, комуникологији, савременим технологијама и њиховој примени у данашњем библиотекарству, медијима и њиховој улози у друштву 21. века, повезаности библиотека и других културних институција.

Катедра за библиотекарство има добру сарадњу са Градском библиотеком „Карло Бијелицки“ у Сомбору, где студенти обављају стручну праксу и стичу неопходна практична знања и вештине. Током протеклих година остварена је успешна сарадња не само са библиотекама у Сомбору (специјалном библиотеком у Градском музеју и основношколским и средњошколским библиотекама), него и са библиотекама у Новом Саду, првенствено Библиотеком Матице српске, Градском библиотеком и Библиотеком Српског народног позоришта. У последње две године студентима је, путем организованих посета, пружена могућност да се упознају и са радом Народне библиотеке у Београду, Универзитетске библиотеке „Светозар Марковић“ и Библиотеке града Београда. Овако осмишљена стручна пракса, кроз рад у сомборским библиотекама, пружа студентима могућност да стекну практичне вештине у свим областима организације рада, набавке, обраде, претраживања, чувања и коришћења различите грађе и извора информација. ${ }^{5}$

Прва генерација мастер студената библиотекарства уписана је школске 2015/16. године. Мастер студије трају годину дана, а студенти добијају интердисциплинарно и интегрисано

\footnotetext{
2 Карла Селихар и Гордана Рудић, „Школовање библиотекара информатичара на Педагошком факултету у Сомбору Универзитета у Новом Саду“ (рад представљен на научном скупу Наука и стварност, Источно Сарајево - Пале, Република Српска, 20. мај 2017), 612

3 Исто.

${ }^{4}$ Селихар и Рудић, „Школовање библиотекара информатичара на Педагошком факултету у Сомбору Универзитета у Новом Саду“, 612.

${ }^{5}$ Исто.
} 
знање, као надоградњу основних студија. Студентима је омогућено упознавање са основама научног рада библиотечко-информационих наука, као и обављање сложенијих стручних функција и послова управљања у савременим библиотекама. Сврха програма је да се мастербиблиотекари информатичари темељно упознају са разноврсним аспектима струке, јер само тако могу бити ефикасни како у традиционалним методама библиотечке делатности, тако и у променљивом електронском окружењу. ${ }^{6}$ Мастер студије је до академске 2018/19. године уписао 41 студент, а њих 20 је успешно одбранило своје мастер радове.

Октобра 2019. године, одлуком Националног тела за акредитацију и проверу квалитета у високом образовању, успешно је окончан процес акредитације докторских студија Библиотекарства, тако да ће Педагошки факултет у Сомбору већ у новембру ове године уписати прву генерацију студената на највишем нивоу академског образовања за нашу професију. Кроз модеран концепт образовања, који подразумева јединство теоријског, практичног и научноистраживачког приступа, студенти ће изучавати и следеће наставне предмете: Библиотеке и савремени свет, Основе комуникологије, Психологија комуникације и медија, Библиографија и организација научног знања, Историја европске цивилизације, Управљање дигиталним документима, Дигитализација културног наслеђа, Управљање пројектима у библиотекама и Медијална дидактика.

\section{Како наћи посао}

Чињеница је да само на територији Војводине раде 344 редовне основне школе и 224 издвојена одељења, 13 основних школа за ученике са сметњама у развоју и инвалидитетом, 21 музичка и две балетске школе, 2 школе за образовање и васпитање одраслих, као и 121 редовна средња школа и 10 средњих школа за ученике са сметњама у развоју. ${ }^{7}$ У основним школама, по подацима Народне библиотеке Србије, ${ }^{8}$ формирано је 330, а у средњим 91 школска библиотека. Због два закона који се примењују у раду школских библиотека, Закону о основном образовању и васпитању и Закону о библиотечко-информационој делатности, млади библиотекари, који су тек завршили студије, имају мале могућности запошљавања. Послове библиотекара у школским библиотекама, по важећим законима и правилницима, имају право да обављају сви запослени са високом стручном спремом.

Ситуација није ништа боља и у другим типовима библиотека, што се првенствено односи на јавне. Дипломирани библиотекари немају предност при запошљавању у односу на друге кандидате. То доводи до алармантног статистичког податка да је, од укупног броја дипломираних библиотекара са сомборске катедре, само њих деветоро нашло запослење у струци.

Поражавајућа је чињеница да у граду и Покрајини у којима се једино школују библиотекари, градске власти немају слуха за запослене у библиотечкој струци. Градска библиотека "Карло Бијелицки“ нашла се прва на удару рационализације радних места у јавном сектору и 2016. године затворено је 14 огранака, а 11 запослених је добило отказе. Међу њима је била и студенткиња прве генерације Школски библиотекар. Иако су сви, одлуком суда, враћени на посао, дошло је до нове рационализације и, у фебруару месецу ове године, отпуштено је троје радника библиотеке. У целој ситуацији најгоре су прошли сеоски огранци, који раде два или три дана у седмици, а у два огранка бригу о корисницима и библиотеци води један библиотекар. Како такав начин рада функционише, најбоље се види и по броју уписаних корисника

\footnotetext{
${ }^{6}$ Селихар и Рудић, Нав. дело, 613.

7 Pokrajinski sekretarijat za obrazovanje, propise, upravu i nacionalne manjine - nacionalne zajednice, "Osnovne škole u AP Vojvodini", preuzeto 1. 10. 2019, http://www.puma.vojvodina.gov.rs/etext.php?ID_mat=1271; Pokrajinski sekretarijat za obrazovanje, propise, upravu i nacionalne manjine - nacionalne zajednice, „Srednje škole u AP Vojvodini”, preuzeto 1. 10. 2019, http://www. puma.vojvodina.gov.rs/etext.php?ID_mat=1286.

${ }^{8}$ Народна библиотека Србије. База МБС, преузето 4. 11. 2019, https://www.nb.rs/pages/article.php?id=1284.
} 
библиотека на селима. Огранак у Станишићу, који је пре три године имао 350 уписаних корисника, и где је библиотека била жила куцавица већине културних дешавања у селу, данас има једва 50 уписаних чланова. Овакве и сличне ситуације не дешавају се само у општини Сомбор. По сазнањима које има Катедра за библиотекарство Педагошког факултета, дипломирани библиотекари - информатичари не пролазе боље ни у другим градовима Покрајине. Поједини свршени студенти имали су прилику да раде као волонтери, али без обзира на школску спрему и потребе библиотека за стручним кадром, због забране запошљавања нису могли да добију сталан посао у библиотеци.

\section{Закључак}

Катедра за библиотекарство Педагошког факултета у Сомбору успешно прати све промене у савременом библиотекарству и примењује их у студијским програмима, како на основним, тако и на мастер студијама. Студенти су по завршетку студија засигурно стручан и оспособљен кадар који, на основу стечених знања, пре свега из библиотечко-информационих наука, може компетентно да обавља послове у свим типовима библиотека. Корисници ових установа постају све захтевнији, а послови библиотекара све бројнији и разноврснији. Оно што је битно јесте чињеница да би струка требало да подржи школовани кадар, као и у свакој професији. У Закону о библиотечко-информационој делатности, као и у Закону о образовању и васпитању, тј. Правилнику о програму свих облика рада стручних сарадника, ${ }^{9}$ требало би јасно дефинисати да школовани стручњаци из области библиотечких наука имају предност при запошљавању. Катедра за библиотекарство и информатику Филолошког факултета Универзитета у Београду, као и Катедра за библиотекарство Педагошког факултета у Сомбору Универзитета у Новом Саду, озбиљно раде свој посао и труде се да за струку „произведу“ добар стручан кадар, који ће компетентно моћи да обавља све врсте послова у било ком типу библиотека. Шта све наведене компетенције вреде када је библиотекар и даље професија која најтеже долази до посла, када су наши стручњаци приморани да ухлебље налазе у другим, често неадекватним пословима, далеко испод својих могућности? Ваљда ће једном и надлежна Министарства, Покрајински секретаријат за културу, јавно информисање и односе са верским заједницама, Покрајински секретаријат за образовање, прописе, управу и националне мањине, надлежни и запослени у библиотекама свих типова који углавном потцењивачки посматрају дипломиране библиотекаре са обе катедре (у Београду и Сомбору), да размисле о будућности и схвате да се важне промене у једној професији не могу спроводити без стручног и школованог кадра. Штитећи своју професију доприносимо и њеном развоју и просперитету, као и што спајањем модерног и традиционалног у образовању библиотекара, стварамо способан кадар, који може одговорити на све захтеве будућности.

\section{Литература и извори:}

1. Narodna biblioteka Srbije. Baza MBS. Preuzeto 4. 11. 2019. https://www.nb.rs/pages/article. php?id=1284.

2. Pokrajinski sekretarijat za obrazovanje, propise, upravu i nacionalne manjine - nacionalne zajednice. "Osnovne škole u AP Vojvodini”. Preuzeto 1. 10. 2019. http://www.puma.vojvodina.gov.rs/etext. php?ID_mat=1271.

\footnotetext{
9 "Правилник о програму свих облика рада стручних сарадника", Службени іласник РС бр. 5 (2012), преузето 29. 9 2019, httр:// www.mpn.gov.rs/wp-content/uploads/2015/08/
} 
3. Pokrajinski sekretarijat za obrazovanje, propise, upravu i nacionalne manjine - nacionalne zajednice. „Srednje škole u AP Vojvodini”. Preuzeto 1. 10. 2019. http://www.puma.vojvodina.gov.rs/etext. php?ID_mat=1286.

4. "Pravilnik o programu svih oblika rada stručnih saradnika”. Službeni glasnik RS br. 5 (2012). Preuzeto 29. 9 2019. http://www.mpn.gov.rs/wp-content/uploads/2015/08/.

5. Selihar, Karla i Gordana Rudić. „Školovanje bibliotekara informatičara na Pedagoškom fakultetu u Somboru Univerziteta u Novom Sadu“. Rad predstavljen na naučnom skupu Nauka i stvarnost, Istočno Sarajevo - Pale, Republika Srpska, 20. maj 2017.

6. Vučković, Željko. „Studije školskog bibliotekarstva“. Pančevačko čitalište 12 (maj 2008): 60-61.

\title{
Librarianship in the Jaws of Life: From Education to Employment
}

\begin{abstract}
Summary
In the Republic of Serbia, librarians are educated at two university departments - the Department of Library and Information Science, Faculty of Philology, University of Belgrade, and the Department of Librarianship, Faculty of Education in Sombor, Novi Sad University. Librarianship studies in Sombor began in 2005, and since 2015 the faculty has been offering the M.A. programme in the field of library and information science. The paper traces the development of the study program at the Department of Librarianship in Sombor and the further path of its students - graduate librarians. Due to the fact that the purpose of the study program is to educate experts in library and information science, after completing four years of study, the graduate librarians/information specialists are trained to perform tasks in all types of libraries. After examining the documentation of the Faculty of Education on the number of students who enrolled in studies and the number of graduate students, the authors analyze how many of them found job in libraries.
\end{abstract}

Keywords: Faculty of Education in Sombor, library studies, librarians, libraries, employment, the Republic of Serbia 


\section{(2) $(\odot \Theta \Theta$}

Библиотекарство у раљама живота: од школовања до запослења bу Карла Селихар, Жељко Вучковић is licensed under a Creative Commons Attribution-NonCommercial-NoDerivatives 4.0 International License. 